\title{
Correlations of Rainfall and Forest Type with Papilionid Assemblages in Assam in Northeast India
}

\author{
Kamini Kusum Barua, ${ }^{1}$ Jolanta Slowik, ${ }^{1}$ Kadiri Serge Bobo, ${ }^{2}$ and Michael Muehlenberg ${ }^{1}$ \\ ${ }^{1}$ Department of Conservation Biology, Georg-August University, Von-Siebold-Straße 2, 37075 Göttingen, Germany \\ ${ }^{2}$ Department of Forestry, University of Dschang, P.O. Box 222, Dschang, Cameroon
}

Correspondence should be addressed to Kamini Kusum Barua, kaminikusum@gmail.com

Received 7 June 2010; Accepted 8 October 2010

Academic Editor: David Roubik

Copyright ( $) 2010$ Kamini Kusum Barua et al. This is an open access article distributed under the Creative Commons Attribution License, which permits unrestricted use, distribution, and reproduction in any medium, provided the original work is properly cited.

\begin{abstract}
No comprehensive community studies have been done on the butterflies of the tropical monsoon forests of the East Himalayan region. We described the Papilionidae at one site within the continuous moist deciduous forest belt of Northeast India and their variation with season and forest type. We surveyed 20 permanent line transects, varying with respect to canopy openness and observed levels of disturbance. A total sample effort of 131 days during the dry and wet seasons of a two-year study resulted in 18,373 individuals identified from 28 Papilionidae species. Constrained canonical correspondence ordination was used to examine the effects of season, forest type, rainfall, year, altitude, and geographical position on the species assemblages. Results showed that rainfall, forest type, and season accounted for most variance in papilionid abundance. Rainfall was strongly correlated with the abundance of some species. Nine species were associated with gaps, 16 species were restricted to closed forest, and three species were encountered in both gaps and closed forest. Six species with narrow geographic range were found only in closed forest. The results confirm the strong seasonality of continental Southeast Asian butterfly assemblages.
\end{abstract}

\section{Introduction}

Studies focusing on insect seasonality have been carried out in many parts of the world including the eecouatorial tropics. Amongst the insects, butterflies form a suitable model group for ecological studies specifically pertaining to seasonality because rainfall and plant phenology are two interrelated factors that influence the life histories of these phytophagous insects [1-3]. The habitat preferences are also closely related to life strategies of different species just as much as the geographical range is related to each species' ecological strategy [4-6].

Butterfly populations are closely controlled by weather and many species are constrained by climate [7-10], reproduce ecouickly, have high dispersal ability and an annual or more freecouent life cycle [11, 12]. Seasonal environments (tropical and temperate regions) and climate gradients like temperature and precipitation play an important role in defining the differences in habitat preferences, biology, adult activity, reproductive strategy, and adaptive polyphenisms of butterflies [13-15].

The IUCN had identified the "Indo-Burma" hotspot as a "Papilionidae-rich zone" and had also drawn up the "Swallowtail Conservation Action Plan" [16]. India occupies the 6th rank in the list of priority countries for "Swallowtail Conservation". From the Indian subcontinent, 84 species had been documented, of which six are endemic [17]. Evans [18] and Talbot [19] described 90 species from the Indian subcontinent; 15 species reported from Ceylon, 19 in South India, 6 in Baluchistan, 11 in Chitral, 50 in southern Burma, 13 in the Andaman and Nicobar islands, 31 in the Western Himalayas, and 69 in North-east India, which is a part of the Eastern Himalayas biodiversity hotspot. In Assam, of the Eastern Himalayas, five species of Papilionidae were listed as endemic [18]. Evans [18] also reported six species as endemic in the entire Sikkim-Assam region. In recent times, records on the papilionids from the Indian Himalayan region were documented by Haribal [20] and Kunte et al. [21]. As few 
studies have focused on butterflies of the Northeast Indian region, and in keeping with the conservation value of this ecoregion, with respect to the Papilionidae, we therefore proposed to investigate the papilionid assemblage within a protected forest reserve in Assam.

The primary vegetation in Northeast India has been disturbed by human activities. The forest ecouality has also been deteriorating with the dense forests (canopy closure $>60 \%$ ) becoming degraded into open-forests or scrub. In Assam the percentage of "Very Dense" forest cover is only 2.1\% $\left(1,684 \mathrm{~km}^{2}\right)$, "Moderately Dense" forest cover is $14.5 \%$ (11, $358 \mathrm{~km}^{2}$ "Degraded/Open forests" is $18.9 \%\left(14,784 \mathrm{~km}^{2}\right)$ and "Nonforest" area is $64.5 \%$ of the total area of forest and tree cover [22]. Under the directives of the National Forest Policy (1988) [23] and the Joint Forest Management (JFM) resolution (1990) [16] involving the local peoples' participation, regeneration and maintenance of degraded forests as well as the protection and conservation of forest resources has assumed priority and significantly contributed towards the management strategies for sustainable forestry in India, including Assam.

This paper aims at documenting the effects of rainfall and habitat on a forest papilionid community in Assam, while also evaluating its conservation status. Thus, we focused on two main ecouestions: (1) is there any difference in the composition and distribution of species assemblages between open-forest or gaps and closed-forest? and (2) is the species abundance and distribution trend within the study area correlated with environmental variables such as season, forest type, year, rainfall, altitude and geographical position (latitude and longitude)?

We hypothesized that (1) papilionid assemblages have a higher species richness in closed-forest as compared to gaps, although in an Amazonian forest fragment, Ramos (2000) found that forest edges and areas of intermediate to high disturbances presented higher species richness and diversity of nymphalid butterfly communities; (2) closedforest supports more species with restricted ranges, as, for example, a high proportion of Papilionidae are primarily forest-dwelling species, but some species are also known to be associated with open habitats [17]; (3) Season, rainfall and forest type may be important determinants for the distribution and abundance of the papilionid assemblage in the study area.

\section{Methods}

2.1. Study Area. The study area is a 23,231 ha protected forest reserve, "Rani-Garbhanga Reserve Forest" located on the south bank of the river Brahmaputra in Assam $\left(26^{\circ} 55^{\prime}\right.$ to $26^{\circ} 0.5^{\prime} \mathrm{N}$ and $91^{\circ} 35^{\prime} \mathrm{E}$ to $91^{\circ} 49^{\prime} \mathrm{E}$ [24], for management purposes, the reserve is divided into two forest ranges- the Garbhanga range (18,861 ha) and the Rani range (4,370 ha). The difference in management is due to the variation in the vegetation structure, regeneration of Sal (Shorea robusta) and Bamboo (Dendrocalamus hamiltonii), replacement of Teak (Tectona grandis) plantations by indigenous species and involvement of local communities in the sustainable management of land-use methods for converting degraded areas into productive ones. Five villages are in the immediate transition zone of this reserve. These fringe villages do have a strong effect on the protected reserve in the form of disturbances like small wood collection, stone ecouarrying, occasional illegal logging, grazing and man-animal conflict. A wetland with a core area of $4.14 \mathrm{~km}^{2}$ (Deepor Beel) lies at the northern boundary of the reserve and is the only Ramsar site in Assam and a representative wetland type found within the biogeographic province "Burma Monsoon Forest" [25]. The forest reserve is also contiguous with the Jarasal-Kwasing Reserve, Nakhalliyang Wildlife Sanctuary and Jirang Unclassed State Forest of the neighbouring state of Meghalaya. It serves as a natural elephant corridor [24] by linking about $70 \mathrm{~km}$ of the reserve from the hills of the Meghalaya plateau into the Deepor Beel in the northern boundary of the reserve (Figure 1).

The forest type in this reserve corresponds to Champion and Seth's [26] "Assam valley tropical mixed moist deciduous forest". This reserve was the original habitat of the "Sal", Shorea robusta with Shorea assamica and Schima wallichii as the principal associate species. However, following excessive logging due to its high commercial viability as a timber yielding species, much of the Sal vegetation was gradually replaced by "moist deciduous secondary bamboo brakes". Shorea robusta, S. assamica, Dipterocarpus macrocarpus, Schima wallichii, Lannea coromandelica, Gmelina arborea, Tetrameles nudiflora, Lagerstoemia parviflora, Bridelia retusa, Albizzia lebbeck and Ficus hispida were observed to be some of the dominant species forming the upper canopy, while the middle storey was composed of Holarrhena antidysenterica, Tricalysia singularis, Oroxylum indicum, Salix tertrasperma, Malletus albus, Careya arborea, Semicarpius anacardium. Dendrocalamus hamiltonii (locally known as Kako Bamboo) was the dominant bamboo species within the forest reserve [27].

We used satellite imagery to select five study sites, covering a total area of 50 ha within the forest reserve. All these sites were partially to heavily disturbed, although the disturbance levels were not ecouantified but evaluated on a visual scale (Table 1). Three of the study sites were located in the Garbhanga range and two sites in the Rani range.

2.2. Sampling Design. Based on the visual levels of disturbance and degree of canopy closure, we demarcated two zones within each study site for butterfly samplingscattered or open-forest (SCF) and Closed forest (CF). We followed the line transect method $[12,28]$ where four transects were selected in each study site- transects $\mathrm{T} 1$ and T2 in SCF and transects T3 and T4 in CF. Thus we had 12 fixed transects in three study sites of the Garbhanga range ( $\mathrm{SCF}=6, \mathrm{CF}=6$ ) and eight transects in two study sites of the Rani range $(\mathrm{SCF}=4, \mathrm{CF}=4)$. Each transect was one kilometer in length and five meters wide and took two observers approximately 30 minutes to walk and record butterflies on both sides of the transect. Species were confirmed by both observers before recording to avoid observer bias [29]. Each transect was sampled usually twice a day, in the morning between 07.00 to $13.00 \mathrm{~h}$ and in the afternoon 14.00 to $17.00 \mathrm{~h}$. The sampling time during 


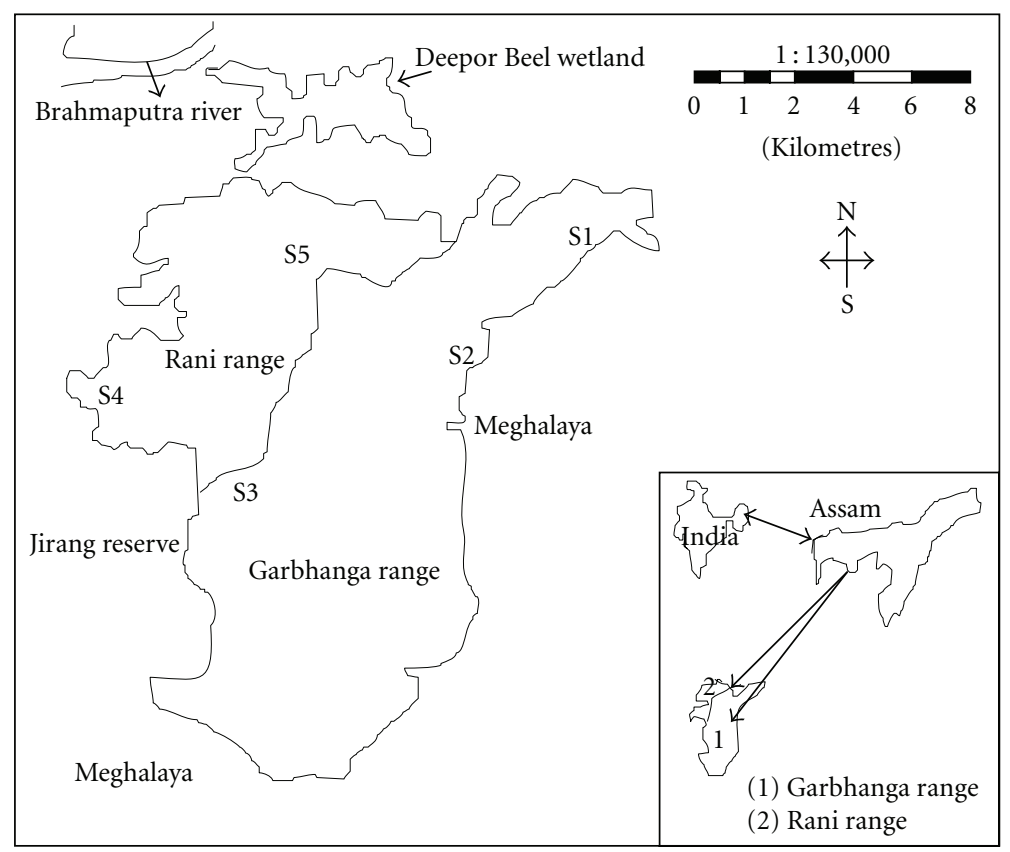

Figure 1: Map of Rani-Garbhanga Reserve forest in Assam, Northeast India.

TABLE 1: Characteristics of the five study sites selected for butterfly sampling.

\begin{tabular}{|c|c|c|c|c|c|}
\hline Study sites & $\begin{array}{l}\text { Geographical } \\
\text { position }\end{array}$ & $\begin{array}{l}\text { Area in } \\
\text { hectares }\end{array}$ & Habitat type and landscape element & $\begin{array}{l}\text { Altitude (m) } \\
\text { above MSL }\end{array}$ & $\begin{array}{l}\text { Level and type of human } \\
\text { disturbance }\end{array}$ \\
\hline S1 & $\begin{array}{l}26^{\circ} 05^{\prime} 26.71^{\prime \prime}- \\
91^{\circ} 46^{\prime} 39.01^{\prime \prime}\end{array}$ & 15 & $\begin{array}{l}\text { Mixed moist deciduous secondary Sal } \\
\text { forest with good cover of grasses }\end{array}$ & 102 & $\begin{array}{l}\text { Partially disturbed human } \\
\text { settlement, earth cutting, small } \\
\text { wood collection }\end{array}$ \\
\hline S2 & $\begin{array}{l}26^{\circ} 03^{\prime} 46.49^{\prime}- \\
91^{\circ} 43^{\prime} 41.56^{\prime \prime}\end{array}$ & 5 & $\begin{array}{l}\text { Mixed-moist deciduous secondary forest } \\
\text { with intermittent tracts of Bamboo } \\
\text { brakes. Closed canopy with trees }>20 \mathrm{~m} \\
\text { in height. Abundance of climbers }\end{array}$ & 130 & $\begin{array}{l}\text { Partially disturbed stone } \\
\text { ecouarrying, earth cutting, selective } \\
\text { logging }\end{array}$ \\
\hline S3 & $\begin{array}{l}26^{\circ} 01^{\prime} 39.18^{\prime \prime}- \\
91^{\circ} 39^{\prime} 03.91^{\prime \prime}\end{array}$ & 5 & $\begin{array}{l}\text { Secondary euphorbiaceous scrub with } \\
\text { grasses growing up to } 10-15 \mathrm{~cm} \text { on the } \\
\text { rocky slopes and hills in the areas near to } \\
\text { the abandoned patches of shifting } \\
\text { cultivation }\end{array}$ & 170 & $\begin{array}{l}\text { Heavily disturbed (shifting } \\
\text { cultivation, illegal logging) }\end{array}$ \\
\hline S4 & $\begin{array}{l}26^{\circ} 01^{\prime} 52.20^{\prime \prime}- \\
91^{\circ} 35^{\prime} 51.32^{\prime \prime}\end{array}$ & 10 & $\begin{array}{l}\text { Degraded secondary deciduous forest } \\
\text { edge with teak plantation, Sal } \\
\text { regeneration, cropland, household } \\
\text { plantation, shrubs and grasses, and } \\
\text { scrubland }\end{array}$ & 100 & $\begin{array}{l}\text { Heavily disturbed (teak plantation, } \\
\text { selective logging, grazing, road } \\
\text { construction, human settlements) }\end{array}$ \\
\hline S5 & $\begin{array}{l}26^{\circ} 04^{\prime} 49.77^{\prime \prime}- \\
91^{\circ} 40^{\prime} 03.07^{\prime \prime}\end{array}$ & 15 & $\begin{array}{l}\text { Secondary mixed deciduous forest near } \\
\text { human settlement }\end{array}$ & 60 & $\begin{array}{l}\text { Heavily disturbed (forest village, } \\
\text { selective logging, intensive grazing) }\end{array}$ \\
\hline
\end{tabular}

the afternoon counts was reduced due to less observed activities of the butterflies. The two-year sampling period was divided into two seasons-Dry season (January-March) and Wet season (August-October) (Figure 2). Our sampling effort was 35 days during the dry season and 42 days during the wet season for study sites S1, S2, and S3 in the Garbhanga range. Studies at S4 and S5 in the Rani range were 27 days each during the dry and wet seasons. The sampling days were different for the study sites of the Garbhanga and Rani ranges. This amounted to nine hours of sampling per day for the three study sites in the Garbhanga range and six hours per day in the two study sites of the Rani range. All sampling activities were carried out on days with sunny weather and a mean daily maximum temperature of $30^{\circ} \mathrm{C}$ during the wet season and $22^{\circ} \mathrm{C}$ during the dry season.

2.3. Collection, Identification, and Geographic Range Classification. The papilionid individuals were collected using butterfly nets whenever identification on the wing was not possible. We used a camera for recording and later counting 


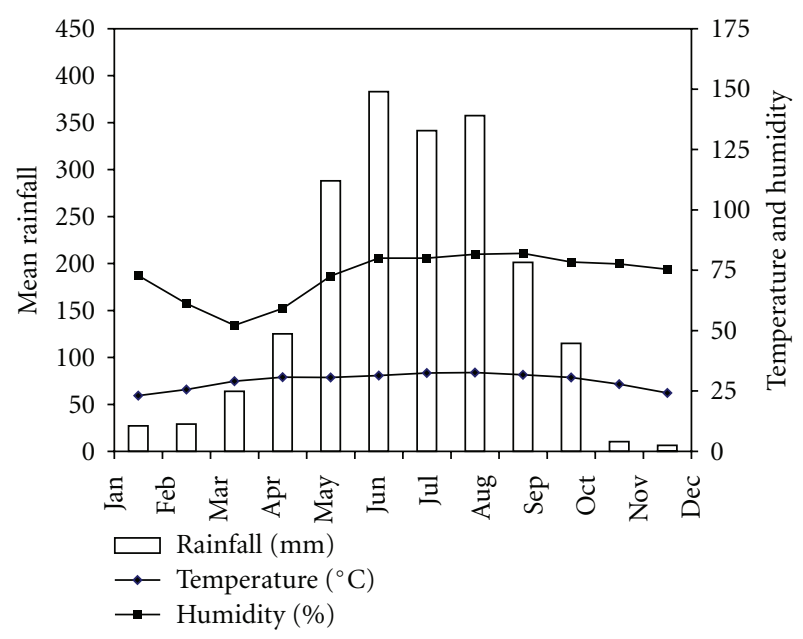

Figure 2: Ombrothermic diagram (Precipitation scale $=2 \times$ Temperature scale) for the study area (mean of years 20012005). The relative humidity is also plotted on the same axis as temperature.

and identifying individuals detected on transects along mudpuddling spots. As within the East-Himalayan Papilionidae, there are polymorphic species [30]; therefore the individual counts for such species were restricted to the species level only. Similarly for the East-Himalayan endemic subspecies, we restricted our sample count to species level only. For species with polymorphic forms as well as for those species that exhibited mimicry, wherever identification on the wing was not confirmed, we excluded such counts in order to avoid sampling bias [29]. We also handled the case of sexual dimorphism and distinct seasonal forms amongst some species in a similar manner.

Identification followed Evans [18], Talbot [19] and Haribal [30] while nomenclature followed Evans [18] and D'Abrera [31]. The geographic distribution ranges had been categorized on a scale of 1-6 (smallest to largest) as used by Spitzer et al. [32]: (1) Eastern Himalayas, Yunnan and Northern Indo-China; (2) North India and all Indo-China; (3) Oriental (Indo-Malayan) region; (4) Indo-Australian region (Australasian tropics); (5) Palaeotropics; (6) Larger than Palaeotropics-Cosmopolitan.

Within the Indian Himalayan Region (IHR), the Indian extent of the Eastern Himalayas includes all of Northeast India. Therefore in our study, the lowest ranked species with score 1 was endemic to the Eastern Himalayas, excluding Yunnan and Northern Indo-China and the highest ranked species with a score 4 was the most widely distributed species. No species with geographic range scores 5 and 6 were recorded in our study area.

2.4. Data Analysis. Canonical Correspondence analysis (CCA) was used for the ordination of the sites, composition and distribution of the species assemblages within the study area. The CCA ordination was run using the axis scores centred and standardized to compartment variance and compartments were plotted on diagrams using linear combination scores in the program $\mathrm{R}$ 2.3.1 (http://cran.r-project.org) [33]. Analyses were done separately for the study sites of the Garbhanga and Rani rangesbutterfly abundance data from the 12 fixed transects in the Garbhanga range and similarly abundance data from eight fixed transects in the Rani range were pooled by season, year and forest type. This amounted to 16 sites scores during the multivariate ordination where each site score in the ordination plots indicated the changing butterfly abundances in the transects by season and year. Site 1 in the ordination plots represented the abundance data from transect $\mathrm{T} 1$ in scattered/open-forest sampled during the dry season of year 1 and site 5 represented the abundance data from the same transect T1 sampled during the wet season of year 1. Similarly, site 9 represented the abundance data from the same transect T1 sampled during the dry season of year 2 and site 13 represented the abundance data from transect T1 sampled during the wet season of year 2 (Appendix 1, see Supplementary Materials available at doi:10.1155/2010/560396).

In order to evaluate environmental effects on mean butterfly abundance, we selected five independent variables within the environment matrix-altitude, geographical position (latitude and longitude), year and rainfall, while season (that subsumes mean maximum temperature, rainfall and humidity) and forest type were used as categorical variables to explain the community structure of the Papilionidae. The first two axes of CCA matrix were plotted as standard plots to compare changes as a result of the environmental variables. The significance of species-environment relationships were tested by running the permutation tests using the "ANOVA" function in the "Vegan" package of the program "R" (Appendices 2 and 3).

Variation in abundance of papilionid individuals between seasons and year were computed by One-Way ANOVA, using the program STATISTICA 7.1 [34].

\section{Results}

3.1. General Aspects. A total of 18,373 individuals representing 28 species (eight genera) were recorded during the study period (Table 2 and Appendix 4). The overall abundance of papilionid individuals recorded in the study sites of the Garbhanga range was higher than in the study sites of the Rani range throughout the study period (Figure 3). Two species, Atrophaneura sycorax and Papilio paris, were not recorded in the Rani range. All species present in the Rani range were also recorded in Garbhanga.

The differences in mean annual transect abundance of butterfly individuals between the dry and wet seasons of the two-year study period were not significant for the study sites of the Garbhanga range (one-way ANOVA, $F_{1,14}=$ 3.9452, $p=0.0669$ ), but significant for the study sites of the Rani range (One-way ANOVA, $F_{1,14}=38.626, p=$ 0.00002 ) (Figure 3 ). Differences in total abundance between the genera were also observed-Graphium and Papilio had highest mean abundances ( $>1000$ individuals) while Chilasa and Lamproptera had the lowest mean abundance $(<100$ individuals) (Table 2). Four endemic species from the genera 


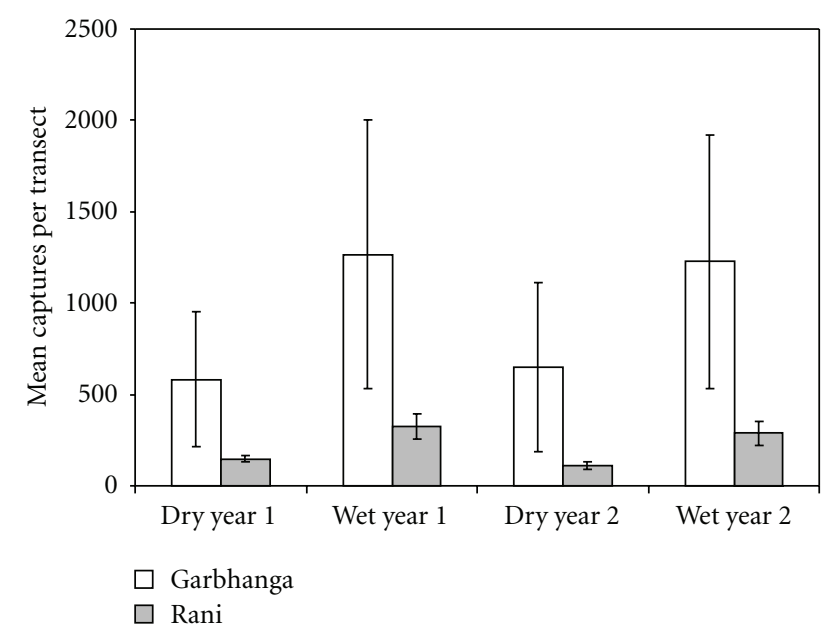

FIGURE 3: Differences in seasonal abundance of papilionids sampled as individuals during the dry and wet seasons of the two years study period from the 20 fixed transects of study sites S1, S2, S3 in Garbhanga (open bars) and S4 and S5 in Rani (dotted bars).

Atrophaneura, Papilio and Pathysa with geographic range score 1 were recorded in our study. Six species from three genera (Graphium, Papilio and Pathysa) had the widest distribution (geographic range 4) while the highest number of species (16) from seven genera was represented by the geographic range score 3 (Appendix 4).

3.2. Ordination of Species Assemblages. The ordination of the species assemblages in the five study sites as shown in the CCA-biplots (Figures 4(a) and 4(b)) clearly indicated the separating effect of forest type as a variable on the papilionid community. Graphium (3 spp.), Pathysa (4 spp.), Pachliopta (1 sp.), and Papilio (1 sp.) were characteristic of the open/scattered forests while Atrophaneura (5 spp.), Troides (2 spp.), Pachliopta (1 sp.), Papilio (7 spp.), and Chilasa (1 sp.) were confined to the closed-forests. Three species (Papilio polytes, Lamproptera meges, L. curius) could be classified as "Intermediate" as they were encountered in both gaps and closed-forests. Six species from the closedforest habitats and two gap species had restricted geographic range score (1 and 2) (Appendix 4).

The site scores in the ordination plots (numbers in black) overlaid on the ordination matrix showed the succession of butterfly abundance with respect to the effects of season and year.

Endemic species from the closed-forest like Atrophaneura dasarada, Atrophaneura varuna, Troides aeacus, Papilio castor and Papilio krishna with restricted geographic ranges 12 were deviated from the center and could be classified as "locally rare" while open-forest species with wider geographic ranges 3-4 like Papilio demoleus, Pathysa antipathies, Pathysa macareus, Papilio memnon were relatively close to the origin and could be classified as "locally common" (Figure 4(a)). Similarly endemic species from the open-forest like Pathysa aristeus and Pathysa xenocles were closer to the origin and could be classified as "locally common". Although
Graphium species recorded the highest total abundance (Table 2), in the constrained ordination matrix, this group assemblage is seen to show a large deviation from the center (Figure 4(a)), which could be implicated either to the fact that they were almost exclusively encountered in the openforest transects or to the significant effect of rainfall on their abundances during the wet season. The ordination of the species assemblages in the study sites of the Rani range showed that fourteen species (belonging to five genera) were confined to the closed-forests while nine species belonging to four genera were associated with the open-forests or gaps. Three species belonging to two genera could be classified as "Intermediate" as they were encountered in both gaps and closed-forest transects (Figure 4(b)). Forest-dependant species like Troides aeacus, T. helena, Papilio polycter, $P$. nephelus, Atrophaneura aidoneus, A. polyceuctes and gap species like Graphium agammemnon, G. doson, Pathsya antipathies, $P$. aristeus and $P$. macareus could be classified as "locally common" species as their positions in the ordination matrix were relatively closer to the origin. Papilio helenus, $P$. castor and Atrophaneura varuna characteristic of the closedforest and Graphium sarpedon, Pathysa xenocles, Pachliopta aristolochiae and Papilio polytes from the open-forests were fairly abundant. There were exceptions where Atrophaneura varuna which is strongly deviated from the centre could be classified as "locally rare" while in case of Papilio demoleus, as this species was mostly encountered in the gaps while the counts from the closed-forest transects were almost negligible, therefore its position in the ordination matrix could be deviated from the centre.

3.3. Variables and Species Abundance in the Study Sites of the Garbhanga Range. The variable "year" was linked with papilionid abundance (Figure 4(a)). Closed forest restricted species like Atrophaneura spp., Troides aeacus, Papilio paris and gap species like Graphium spp. and Pathysa xenocles recorded higher abundances during the wet seasons of the 2 -year study period. The second variable "rainfall" was strongly correlated with abundances of closed-forest species like Atrophaneura dasarada, A. polyeuctes, Papilio paris and gap species like Graphium doson and G. agammemnon. Gap species like Papilio demoleus, Graphium sarpedon, Pathysa sp. and those from intermediate areas like Papilio polytes and Pachliopta aristolochiae showed declining abundances with decreasing rainfall. Altitude as a variable influenced the abundances of the papilionids; closed-forest species recorded greater abundance at higher elevations while gap species recorded higher abundances at lower elevations. The effect of geographical position (latitude and longitude) on papilionid abundance could not be meaningfully explained probably due to the restricted geographical size of the study area.

3.4. Variables and Species Abundance in the Study Sites of the Rani Range. Closed forest species like Papilio helenus, P. castor, Atrophaneura varuna and gap species like Graphium agammemnon, Papilio demoleus, Pachliopta aristolochiae and Lamproptera curius recorded higher abundances during the wet season of the second year of study (Figure $4(\mathrm{~b})$ ). 
TABLE 2: Total number of individuals of Papilionid (per genus) sampled during the dry and wet seasons of 2003-2004 within the study area.

\begin{tabular}{|c|c|c|c|c|c|}
\hline Genus & DS 1 & WS 1 & DS 2 & WS 2 & Total abundance \\
\hline Graphium & 1212 & 2771 & 1886 & 2825 & 8694 \\
\hline Papilio & 1092 & 1784 & 921 & 1653 & 5450 \\
\hline Pathysa & 271 & 456 & 194 & 376 & 1297 \\
\hline Chilasa & 59 & 106 & 46 & 129 & 340 \\
\hline Atrophaneura & 90 & 491 & 87 & 627 & 1295 \\
\hline Troides & 96 & 273 & 100 & 287 & 756 \\
\hline Pachliopta & 65 & 186 & 39 & 143 & 433 \\
\hline Lamproptera & 26 & 39 & 19 & 24 & 108 \\
\hline
\end{tabular}

Notes: DS 1: dry season year 1, WS 1: wet season year 1, DS 2: dry season year 2, WS 2: wet season year 2.

Rainfall strongly affected the abundances of Papilio demoleus, Graphium agammemnon, Pachliopta aristolochiae, Papilio castor, P. helenus, Lamproptera curius and Atrophaneura varuna. The effect of altitude on papilionid species abundance was found to be significant as the gap species recorded higher abundances at lower elevations and the closed-forest species were found to occur in greater abundance at higher elevations. Geographical position did not have a significant influence on the species abundance.

\section{Discussion}

4.1. Species Composition and Association with Forest Type. As we hypothesised, the species composition of our papilionid community was different between the closed and open-forest habitats, with a higher number of restricted range species found in the closed-forest $[5,32,35,36]$.

The choice of forest types by the papilionid assemblage in our study area could have been influenced by several biological factors for the adults-availability of suitable oviposition sites by the gravid females, floral phenology, predators and mimics $[35,37]$. Ecological factors like suitable mud-puddling sites and more sheltered conditions as well as structural variables like size of the area, topography, temperature, humidity, light, gaps and ground pattern could have also accounted for the preference shown by the Papilionidae for different habitats or forest types [5, 32, 35, $38-42]$.

In our present study, the Atrophaneura, Troides and the Papilio spp. were found to prefer the closed-forest habitats. Troides aeacus and Atrophaneura spp. are known to occur [41] in forest gaps and along riparian corridors in tropical forests. In our study area, T. aeacus and A. dasarada recorded higher abundances in closed-forests but sightings were also made in gaps. This could be attributed to the fact that the increased canopy openness and light penetration caused by disturbance increases the abundance of herbaceous growth and vines and favours species freecouenting tree fall gaps and streams for mud-puddling and sun basking [43]. Similarly, the habitat preferences of the seven Papilio spp. could have been affected by structural variables like temperature, light and humidity $[44,45]$.

The geographically wide-ranging Papilio spp. are also migratory species flying over forested areas, thereby giving them an opportunity for visiting flowers in both open habitats and forest canopy (e.g., Papilio paris and P. helenus) [32]. The genera Graphium (3 spp.), Pathysa (4 spp.), Pachliopta (1 sp.), and Papilio (2 sp.) had preferences for the open-forest habitats [32]. They were mostly observed at forest edges near human settlements and gaps created by human disturbances. These species were freecouently observed mud-puddling on wet soil in open sunny patches near human habitations, excreta of domestic animals and foraging on plants like Ixora coccinea, Hibiscus rosa sinensis, Lantana camara and Vitex nugundo that occurred in higher abundances in areas near human settlements. Such opportunists are able to persist in the disturbed landscape, including human settlements, as they are more adaptable and better able to exploit a wide range of ecological niches $[46,47]$. They are known to use a wide range of host plants and therefore can fly over the forest canopy to gaps. This accounts for their wide distribution as opportunist species and may explain our results on higher abundance of the wide-ranging Graphium and Papilio species in the gaps $[48,49]$. The Graphium spp. are known to have expanded their ranges to Cinnamomum tree plantations throughout Southeast Asia [20]. Monoculture of Polyalthia longifolia, an important host-plant of Graphium spp. in human settlements close to the forest edges and gaps as observed in our study could have resulted in high abundances of Graphium spp. This is contradictory to the reports of monoculture-like conditions in plantations of economic trees that are normally known to cause a decline in both floral and butterfly diversity $[21,50]$.

The habitat preferences of the two Lamproptera spp. was categorised as "intermediate" although they were observed to have stronger preferences for the gaps within the study area. Lamproptera curius is a typical gap species [32] and it had showed the lowest abundance amongst all the 28 species recorded in the study area. The status of Lamproptera spp. is "Vulnerable" and there is lack of information on its host plant availability in Assam.

4.2. Effect of Rainfall. In the tropical monsoon climate, the temperature fluctuations between the dry and wet seasons are very little whereas the differences in rainfall are very high. The combined effects of temperature and moisture gradients are known to influence the biology and ecology of butterflies, particularly the variation in adult abundance 


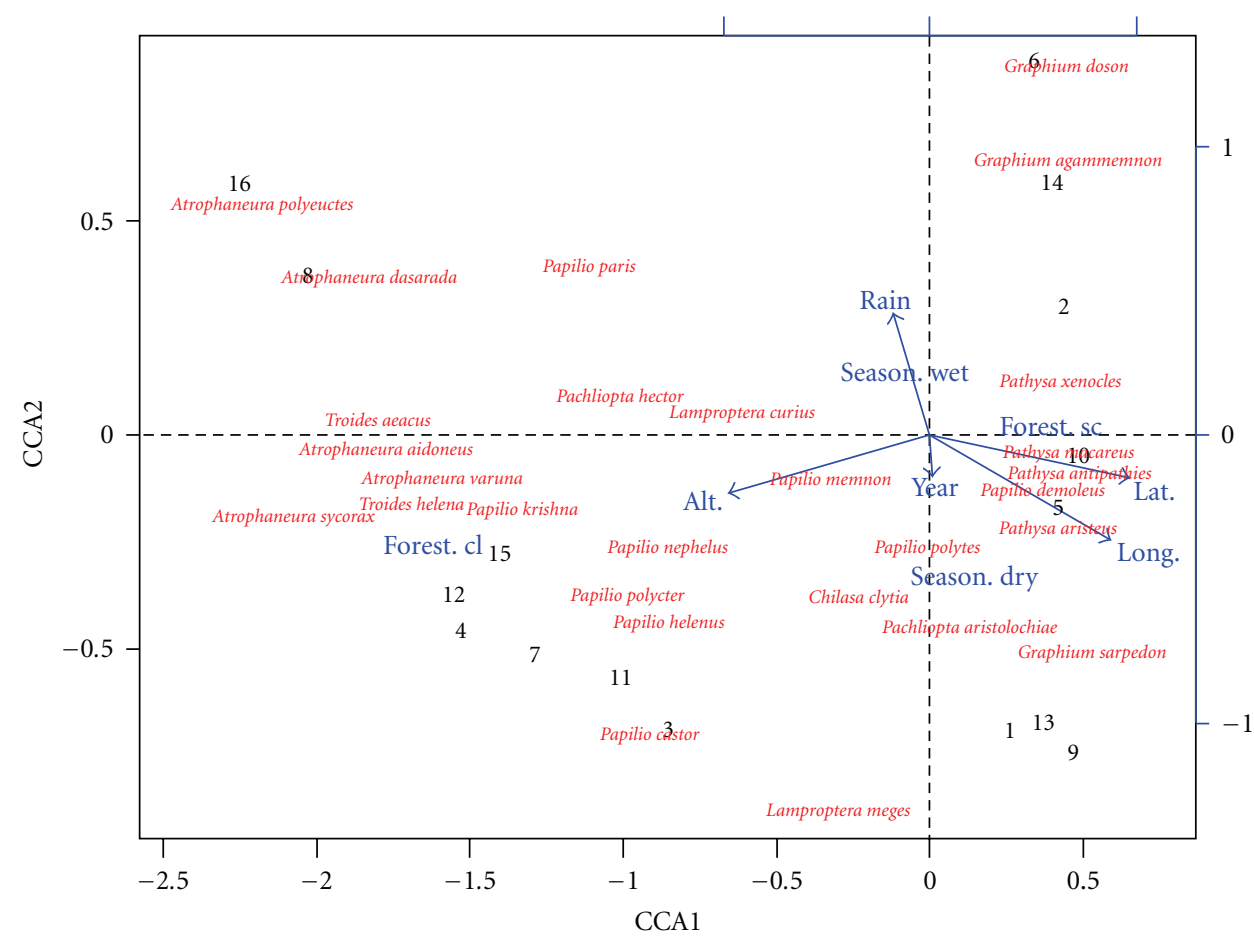

(a) CCA ordination plots of papilionid species matrix on sampling locations of Garbhanga

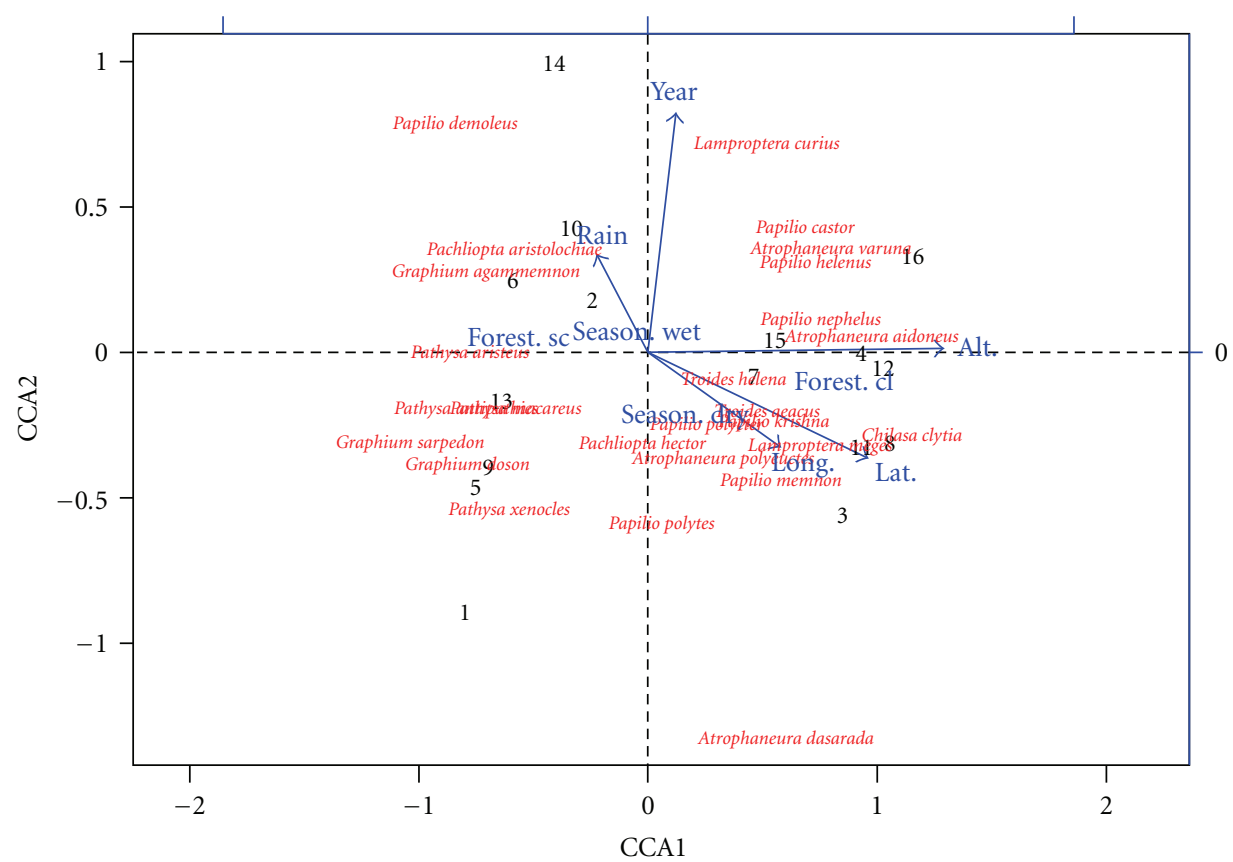

(b) Ordination plots of CCA of Papilionidae species matrix on sampling locations of Rani

FIGURE 4: Ordination plots of CCA of papilionid species matrix on sampling locations of Garbhanga (a) and Rani (b) ranges during the wet and dry seasons of 2003-2004. Note: Lat for latitude, Long for longitude, Alt for altitude, Forest CL for closed forest, Forest SC for scattered/open Forest.

and activity. Arguably, variation in rainfall patterns is the most important factor affecting the seasonality of tropical insects $[51,52]$. Corresponding to our hypothesis, the ordination results showed a strong correlation between rainfall and papilionid abundances, thereby predicting the influence of the monsoon climate on butterfly seasonality. The abundances of species like Papilio demoleus, Pachliopta aristolochiae and Graphium spp., showed a strong correlation with rainfall and were abundant all throughout the monsoon period. Troides aeacus, Troides helena, Papilio helenus and 
Atrophaneura spp. from the closed-forest and Graphium sarpedon, Papilio spp. and Pathysa spp. from the openforests showed moderate seasonal trends with rainfall. While the flight periods of open-forest species reached a peak in the summer months, that of Troides and Atrophaneura spp. peaked during the last part of the wet season, and the flight period of Papilio helenus was found to peak during the late monsoon until the early part of the dry season. Previous studies on the effects of season and habitat on butterfly communities in the northern Western Ghats within the Indian subcontinent reported fluctuations in seasonal abundance with peak populations during late monsoon and early winter [53]. Some species like Pachliopta hector and Papilio castor were strictly seasonal and were found to be on the wing during the monsoons alone. Such a seasonal trend could be attributed to synchrony with the phenology of food plants [41].

\subsection{Effect of Altitude and Geographical Position (Latitude} and Longitude). An effect of altitude on the abundance and distribution of the Papilionidae was indicated in our study area. The forest species preferred the higher elevations while the open-forest species preferred the gaps at lower elevations. Although the altitudinal variation in the sampled transects were not large, differences in abundances between open and closed-forests were observed. Narrow elevational gradients could sometimes influence some of the biological activities of the butterflies, like fecundity and opportunities to lay eggs [54]. The sampling design might have also affected the results as gaps were mostly located at lower elevations. The sampling scale was also small which might explain why we did not find a pronounced effect of the geographical position on papilionid abundance.

4.4. Conclusion and Recommendations for Conservation. Our overall study results showed that papilionid abundance was influenced by the seasonal monsoon climate and this was in agreement with the findings of Spitzer et al. [32] and Leps and Spitzer [5]. Our results were also in conformity with our hypothesis on higher species richness in the closedforest habitats. Sixteen out of 28 species were found to be associated with the closed-forest, and six species with restricted geographic range scores (1-2).

Species like the Bhutan Glory (Bhutanitis lidderdalei) and Kaiser-I-Hind (Teinopalpus imperialis), which were already listed as rare in the Assam region in the early part of the 20th century, have not been sighted in several years. They were subjected to extensive commercial trade. But there are many more species, which have not been recorded since their early documentation, and it is not known whether they still exist. The Yellow-Crested Spangle (Papilio elephenor), an IUCN Red-listed species endemic to the Eastern Himalayas, which was last reported from Assam in 1907 [55] was spotted in a protected reserve in western Assam in 2009 (Eastern Himalayas Bulletin 2009). The area where this species has been sighted is still a pristine habitat although reports of human pressure on the reserve clearly indicate the existing threats to the habitat. The conversion of primary forest cover into secondary forests and open scrublands will destroy the pristine habitats and the papilionids, which are primarily a forest group, will be most affected, because their hostplants will disappear. Based on previous records of high Papilionidae diversity in the Eastern Himalayas, we therefore considered it logical to investigate a protected secondary forest reserve within the moist deciduous forest zone of Assam. Large scale deforestation and habitat fragmentation has led to a decline in the butterfly population in Assam during the last decade and the status of many species which were listed as common during the early part of the 20th century is presently not clear. Most of the protected reserves do not even have inventories of butterflies. In India, butterflies have been recently included in biodiversity conservation programmes [56]. Research and documentation of butterflies needs to be re-initiated in the Assam region, with conservation priorities to be focused on stenotopic closed canopy species that are also the most endangered groups [42]. Monitoring of butterfly populations and ecological studies focusing on the possible causes of decline and developing conservation strategies in protected areas have to be initiated in order to save the remaining populations from extinction. It is also essential to bring more forests under a protected area network. A wildlife sanctuary for butterfly conservation under the Indian Wildlife (Protection) Act, 1972 [57] would serve an important purpose.

Northeast India was largely closed to the outside world for the last fifty years primarily due to its remote location, sharing the international boundary with several countries and an uniecoue cultural identity. Apart from being a biodiversity hotspot, this region is also a cultural hotspot with over 240 distinct ethnolinguistic groups [27]. In recent decades, deforestation and watershed deterioration have progressed rapidly due to land clearing by both the local and migrant population and heavy demand for timber from neighbouring Bangladesh and other urban centers of India. Shifting cultivation largely practiced by the hill tribes is another major issue. Although the indigeneous communities are recognized as the rightful stakeholders of much of the forest land in Northeast India, there is still a lack of external support within the legal policy framework due to the larger economic interests of the private sectors and government agencies. However there is a great scope for community based forest management due to a very rich heritage of Traditional Ecological Knowledge system (TEK) and the need for actions that promote the conservation and sustainable use of the region's endangered forests and the changing land-use practices in the last fifty years. Promotion of eco-tourism that will primarily focus on "butterfly watching" can also help in generating an alternative source of livelihood for the forest fringe villagers. We also call for the development of a resource database on butterfly biology in the Assam region as it has been shown to be critical for butterfly conservation $[39,40]$.

\section{Acknowledgments}

The authors would like to thank the Department of Forests, Government of Assam, India for the permission granted to conduct the research study in Rani-Garbhanga Reserve Forest. They would like to thank the Ministry of Environment 
and Forests, Government of India for the financial grant and the research team in the Department of Zoology, Gauhati University, Assam for the fieldwork. The authors acknowledge the special contribution of Dr. Matthias Waltert, Centre for Nature Conservation, University of Göttingen, who has given the scientific inputs and helped in the drafting of the paper. Special thanks are due to N. K. Bhagobaty, Senior Instructor, Institute of Advanced Study in Science and Technology, Guwahati, Assam, India for assistance with the statistical analyses. In authorship they followed the "FLAE" norm.

\section{References}

[1] H. Wolda, "Seasonal fluctuations in rainfall, food and abundance of tropical insects," Journal of Animal Ecology, vol. 47, pp. 369-381, 1978.

[2] H. Wolda, "Fluctuations in abundance of tropical insects," American Naturalist, vol. 112, pp. 1017-1045, 1978.

[3] H. Wolda, "Insect seasonality: why?" Annual Review of Ecology and Systematics, vol. 19, pp. 1-18, 1988.

[4] K. Spitzer and J. Leps, "Determinants of temporal variation in moth abundance," Oikos, vol. 53, no. 1, pp. 31-36, 1988.

[5] J. Leps and K. Spitzer, "Ecological determinants of butterfly communities (Lepidoptera, Papilionoidea) in the Tam Dao Mountains, Vietnam," Acta Entomologica Bohemoslovaca, vol. 87, no. 3, pp. 182-194, 1990.

[6] V. Novotny, "Effect of habitat persistence on the relationship between geographic distribution and local abundance," Oikos, vol. 61, no. 3, pp. 431-433, 1991.

[7] E. Pollard, "Population ecology and change in range of the White Admiral butterfly Ladoga camilla L. in England," Ecological Entomology, vol. 4, pp. 61-74, 1979.

[8] E. Pollard, "Temperature, rainfall and butterfly numbers," Journal of Applied Ecology, vol. 25, no. 3, pp. 819-828, 1988.

[9] D. B. Roy and T. H. Sparks, "Phenology of British butterflies and climate change," Global Change Biology, vol. 6, no. 4, pp. 407-416, 2000.

[10] J. R. G. Turner, C. M. Gatehouse, and C. A. Corey, "Does solar energy control organic diversity? Butterflies, moths and the British climate," Oikos, vol. 48, no. 2, pp. 195-205, 1987.

[11] C. Parmesan, "Climate and species' range," Nature, vol. 382, no. 6594, pp. 765-766, 1996.

[12] E. Pollard and T. J. Yates, Monitoring Butterflies for Ecology and Conservation, Chapman \& Hall, London, UK, 1993.

[13] P. M. Brakefield and T. B. Larsen, "The evolutionary significance of dry and wet season forms in some tropical butterflies," Biological Journal of the Linnean Society, vol. 22, no. 1, pp. 1-12, 1984.

[14] L. McLeod, "Seasonal Polyphenism in African Precis butterflies," in Vane-Wright RI, P. R. Ackery, Ed., vol. 11 of The Biology of Butterflies. Symposium of the Royal Entomological Society, pp. 313-315, Academic Press, London, UK, 1984.

[15] D. F. Owen, Camouflage and Mimicry, Oxford University Press, Oxford, UK, 1980.

[16] MOEF (Ministry of Environment and Forests), Joint Forest Management Resolution, of Environment, Forests and Wildife, Government of India, New Delhi, India, 1990.

[17] N. M. Collins and M. G. Morris, Threatened Swallowtail Butterflies of the World. IUCN Red Data Book, IUCN, Cambridge, UK, 1985.

[18] W. H. Evans, The Identification of Indian Butterflies, Bombay Natural History Society, Mumbai, India, 2nd edition, 1932.
[19] G. Talbot, The Fauna of British India, Including Ceylon and Burma. Butterflies Vol. I. (Papilionidae \& Pieridae), Taylor and Francis, London, UK, 1939.

[20] M. Haribal, Butterflies of Sikkim Himalaya and Their Natural History, Sikkim Nature Conservation Foundation (SNCF), Gangtok, India, 1994.

[21] K. Kunte, D. Agashe, and P. Date, Checklist of Butterflies of India. Digitized Version of Information from W.H.Evans's Identification of Indian Butterflies, 2nd edition, 2005.

[22] FSI, State of Forest Report 2003, Forest Survey of India. Ministry of Environment and Forests, Dehradun, India, 2003.

[23] MOEF (Ministry of Environment and Forests), The National Forest Policy, Government of India, New Delhi, India, 1988.

[24] J. Borah, K. Thakuria, K. K. Baruah, N. K. Sarma, and K. Deka, "Man-elephant conflict problem: a case study," Zoos' Print Journal, vol. 20, no. 7, pp. 22-24, 2005.

[25] IUCN Directory of South Asian Protected Areas, IUCN, Cambridge UK, 1990.

[26] H. G. Champion and S. K. Seth, The Forest Types of India, The Manager of Publications, Delhi, India, 1968.

[27] K. K. Barua, Diversity and habitat selection of papilionidae in a protected forest reserve in assam, Northeast India, Ph.D. thesis, Dissertation in Biology, University of Göttingen, 2008.

[28] E. Pollard, "A method for assessing changes in the abundance of butterflies," Biological Conservation, vol. 12, no. 2, pp. 115134, 1977.

[29] R. L. H. Dennis, T. G. Shreeve, N. J. B. Isaac et al., "The effects of visual apparency on bias in butterfly recording and monitoring," Biological Conservation, vol. 128, no. 4, pp. 486492, 2006.

[30] M. Haribal, The Butterflies of Sikkim Himalaya, Sikkim Nature Conservation Foundation (SNCF), Gangtok, India, 1992.

[31] B. D'Abrera, Butterflies of the Oriental Region. Part 1, Hill House, Melbourne, Australia, 1982.

[32] K. Spitzer, V. Novotny, M. Tonner, and J. Leps, "Habitat preferences, distribution and seasonality of the butterflies (Lepidoptera, Papilionoidea) in a montane tropical rain forest, Vietnam," Journal of Biogeography, vol. 20, no. 1, pp. 109-121, 1993.

[33] R. Ihaka and R. Gentleman, "A language for data analysis and graphics," Journal of Computational and Graphical Statistics, vol. 5, no. 3, pp. 299-314, 1996.

[34] Statsoft, STATISITICA for Windows, Statsoft, Tulsa, Okla, USA, 1995.

[35] F. A. Ramos, "Nymphalid butterfly communities in an Amazonian forest fragment," Journal of Research on the Lepidoptera, vol. 35, pp. 29-41, 2000.

[36] K. Spitzer, J. Leps, and T. Soldan, "Butterfly communities and habitat of seminatural savanna in southern Vietnam (Papilionoidea, Lepidoptera)," Acta Entomologica Bohemoslovaca, vol. 84, pp. 200-208, 1987.

[37] J. A. Thomas, "The ecology and conservation of Maculinea arion and other European species of large blue butterfly," in Ecology and Conservation of Butterflies, A. S. Pullin, Ed., pp. 180-210, Chapman and Hall, London, UK, 1995.

[38] L. Boriani, G. Burgio, M. Marini, and M. Genghini, "Faunistic study on butterflies collected in Northern Italy rural landscape," Bulletin of Insectology, vol. 58, no. 1, pp. 49-56, 2005.

[39] R. L. H. Dennis, T. G. Shreeve, and H. van Dyck, "Towards a functional resource-based concept for habitat: a butterfly biology viewpoint," Oikos, vol. 102, no. 2, pp. 417-426, 2003.

[40] R. L. H. Dennis, T. G. Shreeve, and H. van Dyck, "Habitats and resources: the need for a resource-based definition to conserve butterflies," Biodiversity and Conservation, vol. 15, no. 6, pp. 1943-1966, 2006. 
[41] K. Spitzer, "Seasonality of the Butterfly Fauna in Southeastern Vietnam (Papilionoidea)," Journal of Research on the Lepidoptera, vol. 22, no. 2, pp. 126-130, 1983.

[42] K. Spitzer, J. Jaroš, J. Havelka, and J. Lepš, "Effect of smallscale disturbance on butterfly communities of an Indochinese montane rainforest," Biological Conservation, vol. 80, no. 1, pp. 9-15, 1997.

[43] J. Ghazoul, "Impact of logging on the richness and diversity of forest butterflies in a tropical dry forest in Thailand," Biodiversity and Conservation, vol. 11, no. 3, pp. 521-541, 2002.

[44] W. S. Blau, "The effect of environmental disturbance on a tropical butterfly population," Ecology, vol. 61, pp. 1005-1112, 1980.

[45] J. K. Hill, "Butterfly spatial distribution and habitat requirements in a tropical forest: impacts of selective logging," Journal of Applied Ecology, vol. 36, no. 4, pp. 564-572, 1999.

[46] A. H. Harcourt, S. A. Coppeto, and S. A. Parks, "Rarity, specialization and extinction in primates," Journal of Biogeography, vol. 29, no. 4, pp. 445-456, 2002.

[47] M. J. Jones, M. S. Sullivan, S. J. Marsden, and M. D. Linsley, "Correlates of extinction risk of birds from two Indonesian islands," Biological Journal of the Linnean Society, vol. 73, no. 1, pp. 65-79, 2001.

[48] D. Jablonski, "Extinctions: a paleontological perspective," Science, vol. 253, no. 5021, pp. 754-757, 1991.

[49] L. P. Koh, N. S. Sodhi, and B. W. Brook, "Ecological correlates of extinction proneness in tropical butterflies," Conservation Biology, vol. 18, no. 6, pp. 1571-1578, 2004.

[50] M. R. Borkar and N. Komarpant, "Diversity, abundance, and habitat associations of butterfly species in bondla wildlife sanctuary of Goa, India," Zoos' Print Journal, vol. 19, no. 10, pp. 1648-1653, 2004.

[51] J. K. Hill, K. C. Hamer, M. M. Dawood, J. Tangah, and V. K. Chey, "Rainfall but not selective logging affect changes in abundance of a tropical forest butterfly in Sabah, Borneo," Journal of Tropical Ecology, vol. 19, no. 1, pp. 35-42, 2003.

[52] H. Wolda, "Seasonal cues in tropical organisms. Rainfall? Not necessarily!", Oecologia, vol. 80, no. 4, pp. 437-442, 1989.

[53] K. J. Kunte, "Seasonal patterns in butterfly abundance and species diversity in four tropical habitats in northern Western Ghats," Journal of Biosciences, vol. 22, no. 5, pp. 593-603, 1997.

[54] C. L. Boggs and D. D. Murphy, "Community composition in mountain ecosystems: climatic determinants of montane butterfly distributions," Global Ecology and Biogeography Letters, vol. 6, no. 1, pp. 39-48, 1997.

[55] C. T. Bingham, "The Fauna of British India, including Ceylon and Burma," Butterflies, vol. I-II, article 39, 1907.

[56] M. Gadgil, "Documenting diversity: an experiment," Current Science, vol. 70, no. 1, pp. 36-44, 1996.

[57] IWPA, Indian Wildlife (Protection) Act 1972 (As Amended upto 2006), Wildlife Trust of India, New Delhi, India, 1972. 

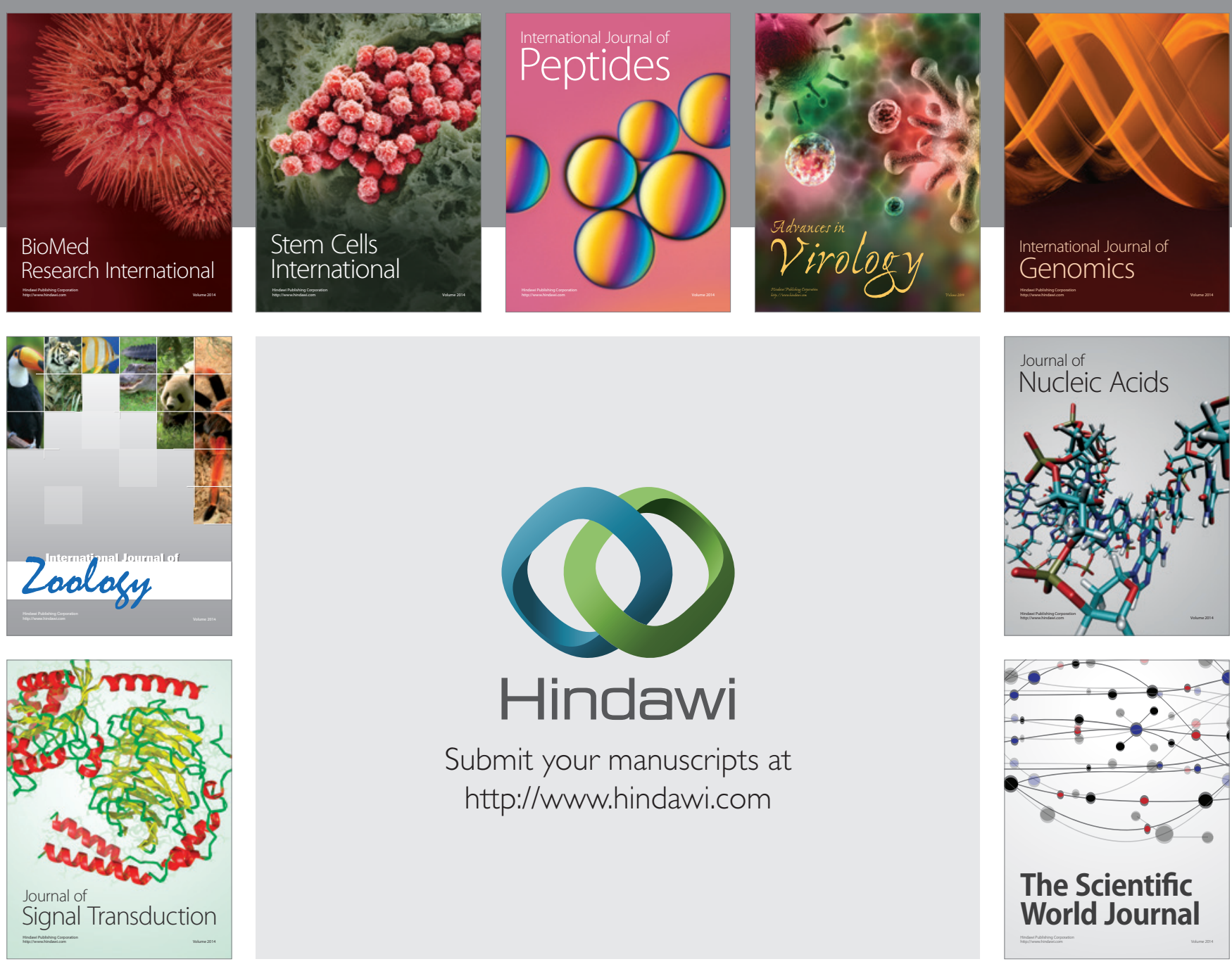

Submit your manuscripts at

http://www.hindawi.com
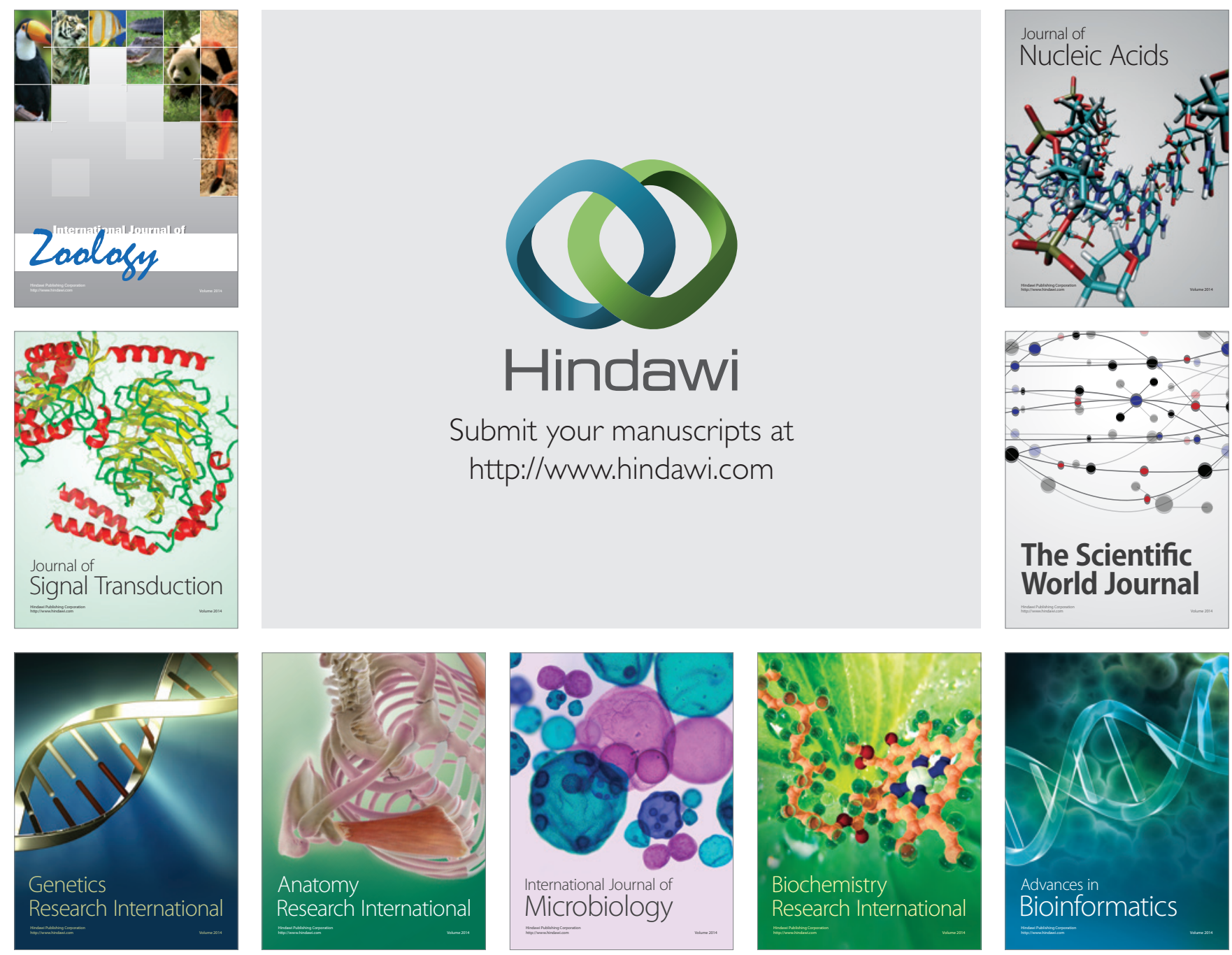

The Scientific World Journal
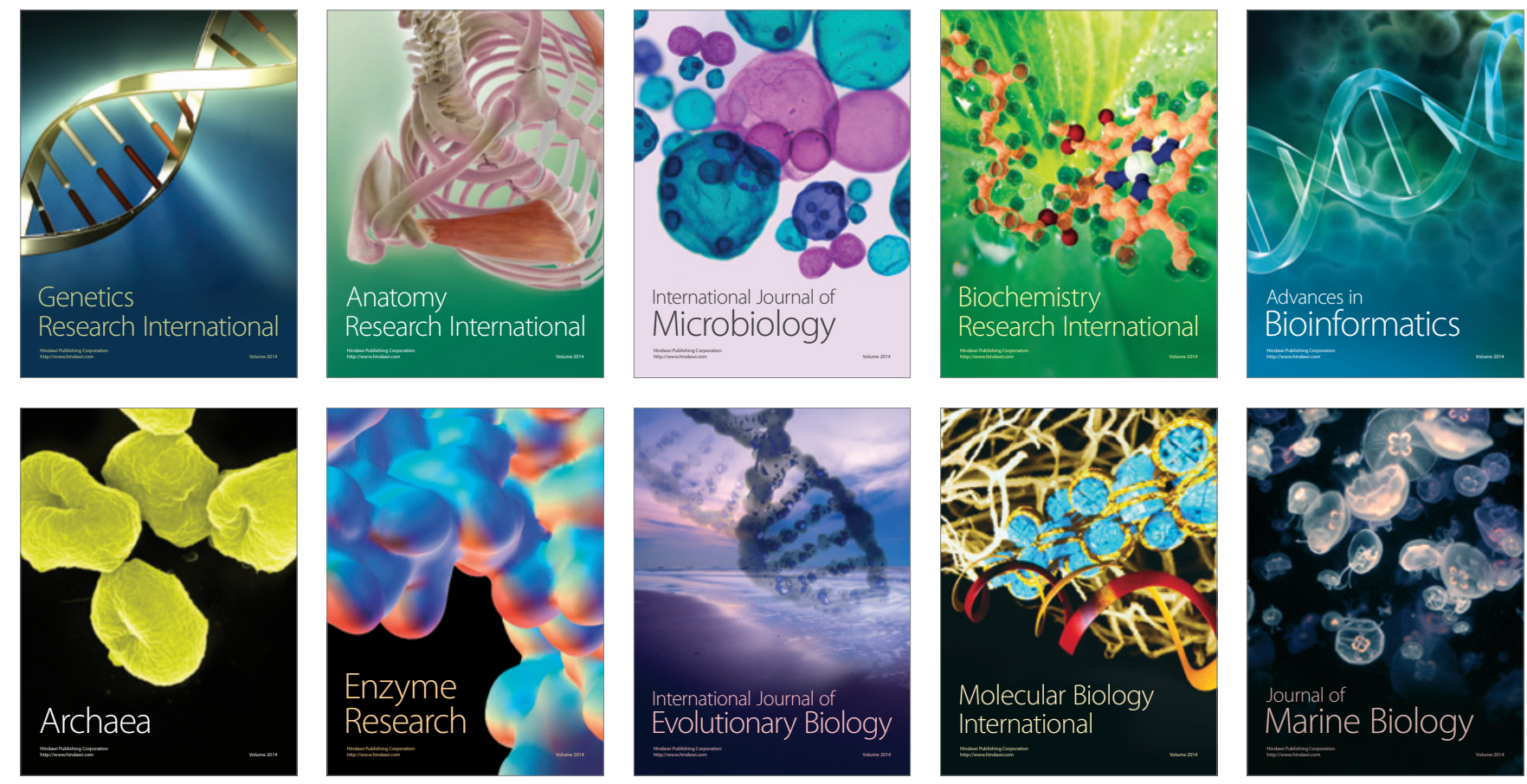